\title{
2. 情報ディスプレイ
}

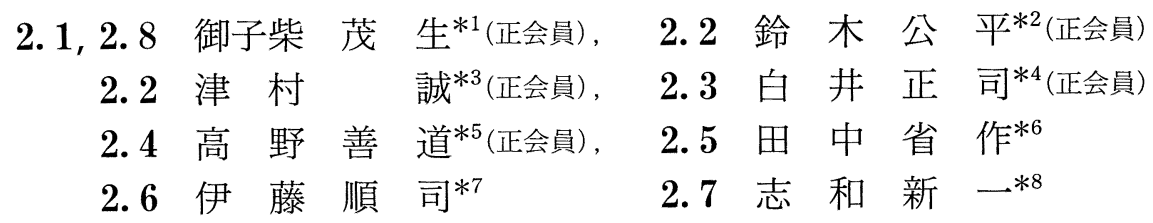

\section{1 ま え がき}

1994 年度と 1995 年度の 2 年間, 情報ディスプレイ 研究・開発の進展, および事業規模の拡大は, 従来に も増して著しかった，LCD (Liquid Crystal Display) は, 従来困難であるといわれてきた大型化，広視野角 化，反射型などが着実に実現されつつある。大型 CRT (Cathode Ray Tube) は，多くの技術者の予想 に反して NTSC (National Television System Committee) 用横長テレビが秋葉原を支配している. CRT および LCD 投射型ディスプレイの画質は，これが昔 の投射型と同じデバイスか, と驚くほど改善されてき た。これに加えて, DMD (Digital Micromirror Device）が頭角を現してきた。輝度，画質など CRT や LCD 投射型を追い抜く勢いである. 歩留まりは $95 \%$ と高く, 家庭向けの低コスト化も可能である. 劇 場用大画面にも適している.

この 2 年間での最大のニュースは, 対角 40 インチ 程度の大型 PDP (Plasma Display Panel) の事業化で あろう. 1995 年 4 月以降, 数社がそれぞれ数百億か

\footnotetext{
$* 1$ 電気通信大学 電子工学科

*2 株式会社東芝 研究開発センター

$* 3$ 株式会社日立製作所 日立研究所

*4 株式会社日立製作所 電子デバイス事業部

*5 NHK 放送技術研究所 イメージデバイス研究部

*6 鳥取大学 電気電子工学科

*7 電子技術総合研究所 プロセス基礎研究室

*8 株式会社 ATR 通信システム研究所 知能処理研究室

“2. Information Display” by Shigeo Mikoshiba (The University of Electro-Communications, Tokyo), Kouhei Suzuki (Toshiba Corp., Tokyo), Makoto Tsumura (Hitachi, Ltd., Hitachi), Shoji Shirai (Hitachi, Ltd., Mobara), Yoshimichi Takano (NHK Science and Technical Research Laboratories, Tokyo), Shosaku Tanaka (Tottori University, Tottori), Junji Itoh (Electrotechnical Laboratory, Tsukuba) and Shinichi Shiwa (ATR Communication Systems Research Laboratories, Kyoto)
}

ら一千億円規模の投資計画を発表し，ディスプレイ事 業におけるポス卜液晶となる候補が確定した模様であ る.この計画はインフラを担当する多数の企業によっ て支えられているが，これはちょうど液晶事業が大き く立ち上がった時の状態に似ている. LED (Light Emitting Diode）に関する大ヒットは, 高輝度青色発 光素子開発の成功である。これでLED ディスプレイ のフルカラー化が事実上可能となった.

(御子柴)

\subsection{LCD}

液晶ディスプレイはこの 2 年間に大幅な技術進歩が あった，単なる改良というよりも次世代に向けた数久 の飛躍であった．

\subsection{1 デバイス開発の動向概説}

液晶ディスプレイは, 直視型と投射型に大別され, 直視型はさらにバックライト光源を用いた透過型と, 光源不要で超低消費電力化が可能な反射型に分けられ る。な扔，方式面からは，TFT (Thin Film Transistor) 等のアクティブ素子を用いたアクティブマトリク ス型と，それを用いないパッシブマトリクス型に大別 されるなど, 様々な分類があるが, それらは要素技術 の項に譲り,ここでは性能主体で述べる.

直視透過型では, 高画質化を筆頭に低消費電力化や 大画面化が大幅に進み, 低コスト化技術も進歩した。 画質の面では, 液晶ディスプレイで最大の弱点であっ た視野角が大きく改善され, 上下左右 $445^{\circ}$ でコント ラスト 10 以上と, CRT と遜色ない程度のものも開発 された。高精細化は液晶ディスプレイの得意な領域で あり, カラーでは 157 万画素, モノクロでは 630 万画 素（横 $3072 \times$ 縦 2048 画素）で 300 dpi（dot per inch） と印刷物に迫る精細度のものまで現れた。低消費電力 化では, バックライトの光利用効率を大幅に高める技 術や, 駆動回路系の消費電力を半減させる技術が現 
れ，現行製品の消費電力 (パソコン用で $2 \mathrm{~W}$ 前後) が 半減するのも近いであろう. 大画面化については, 1 枚パネルでは対角 20 インチ前後まで大型化してきて いるが,ささら張り合わせ技術を用いた対角 28 イン チや 90 インチのものも発表された。低コスト化に関 しては, ガラス基板上に駆動回路を低温プロセスで表 示部と一体に作り込めるようになった。

直視反射型は, 携帯情報端末の市場性の高まりとと もに，開発が非常に活発になってきた．従来の反射型 の弱点であった反射率など見やすさに関する事項, お よびカラー化の点で大きく飛躍した，反射率は現状の 製品レベルの 2 倍程度のものが報告されている，反射 率の值は測定条件に依存するため一概にはいえない が, モノクロタイプでは $50 \%$ を越えるものも現れ， 紙の反射率に近づいてきた. 精細度も向上し, 約 100 万画素で $100 \mathrm{dpi}$ の精細度を持つ A 4 サイズ大（14 イ ンチ）のビュワーも現れた。ささらにこれをフィルム 化しペン入力機能を持たせたものも発表された. カラ 一化は, まず 4 色程度のマルチカラーのディスプレイ が開発され, 将来のフルカラー化を目指した表示方式 の発表が始まった。

投射型は, 数インチの液晶パネル上の画像を数 10１00 インチ程度のスクリーンに拡大投射する. 従 来の課題であった高輝度・高効率化が大幅に進み, 6.3 $\mathrm{lm} / \mathrm{W}$ の高い光利用効率が得られるものも発表され た. 画素数ではHDTV クラスがすでに実現されてお り，低コスト化を目的とした液晶パネルの小型化・画 素微細化が進んだ。

\subsection{2 要素技術}

ドライバ回路と画素をガラス基板上に同時形成する 回路内蔵技術において, poly-Si TFT の低温形成と 高性能化に大きな進展が見られた。 $400^{\circ} \mathrm{C}$ 以下の低温 プロセスでも, ドライバ回路として充分な駆動電流を 得ることができるようになった ${ }^{1)}$.この温度だと, 比 較的安価な硼珪酸系ガラス基板を使用することができ る.ボトムゲート TFT 構造と, 大面積基板に適用可 能なリニアビームエキシマレーザ照射の組合せで形成 する. LPCVD (Low Pressure Chemical Vapor Dep-

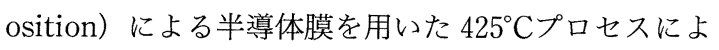
る 10.4 インチ SVGA パネルの開発2) が報告されてい る. 高性能化については, オフセット部を自己整合型 の陽極酸化膜で作成した低オフ電流の TFT-LCD ${ }^{3)}$, LDD (Lightly Doped Drain) 構造によりオフ電流を $0.1 \mathrm{pA}$ 以下に低減したTFT の開発出, さらに $600^{\circ} \mathrm{C}$ プロセスにおいて電界効果移動度が $440 \mathrm{~cm}^{2} / \mathrm{V} ・ \mathrm{~s}$ を 達成した試作 ${ }^{5)}$ が見られる。また， $a-\mathrm{Si}$ TFTを使っ
た回路内蔵技術として, デマルチプレクサ方式のデー タドライバと走査回路をフル内蔵したディスプレイの 開発吕が報告されている.

超低消費電力の携帯型情報機器用反射型表示モード の開発に関しては, 反射率の向上とカラー表示技術が 活発化している。広視野角を特徴とするゲスト・ホス ト型表示モードにおいて, 反射板に適度な散乱性を付 与することにより明るいモノクロ表示》が実現でき た.フルカラーの動画表示が可能な表示モードの開発 も発表されている ${ }^{8) 99}$. この他にも, カイラルピッチ を紫外線照射量により制御し, 3 原色を選択的に表示 できるドットを形成する方法 ${ }^{10)}$ が検討されている. また，表示にメモリー性のあるコレステリック液晶の 選択反射を用いた表示モードの開発も行われ, 高コン トラストで高精細のディスプレイが試作されてい $ろ^{1112)}$.

バックライトを用いる透過型の表示モードにおいて も, 光の利用効率を向上するため多方面にわたる検討 がなされている. 遮光とゲート線の冗長を兼用した遮 光構造により開口率を $70 \%$ まで向上させたパネル13), 遮光層を顔料分散型の感光性ポリマーで形成した完全 セルフアライン構造 TFT-LCD ${ }^{14)}$, 偏光変換機能を 持たせて偏光板のロスを大幅に低減させたバックライ ト $^{15) 16)}$, 導光体の散乱性を高めた高効率バックライ ト ${ }^{17)}$, さらにホログラムにより白色光を分光して導光 するバックライト ${ }^{18)}$ などが報告されている.また， 光学系の効率向上により回路系の消費電力の割合が相 対的に増大してきたことを受けて, 低消費電力駆動技 術の開発も活発化してきている. 信号線の極性反転周 期を伸ばすことにより消費電力を低減できることを応 用し, サブフィールドを設け規則的に画素を間引く方 法でフリッカを抑制して回路消費電力を $1 / 2$ 以下にす る開発 ${ }^{19)}$ や，信号ドライバ内にメモリーを持たせ， ディスプレイ用外付けメモリーを省略して低消費電力 化した開発 ${ }^{20)}$ が報告されている。

透過型の表示モードの広視野角化技術に関して大き な進歩が見られた。一つの画素を, 視角依存性を補償 する2つのドメインに分割するデュアルドメイン 法 $^{2122)}$, アモルファス状態の TN (Twisted Nematic) 液晶をサブピクセルに分割して紫外線を照射すること によりドメイン領域を形成するスーパーマルチドメイ ン法 ${ }^{23)}, 4$ つの領域に分け, さらに視野角特性を向上 させた 4 分割ドメイン法 ${ }^{2425)}$ などが提案されている. また, 平行配向したネマチック液晶を基板面と平行な 平面で駆動するインプレーンスイッチングモードが開 発され, CRTに近い広視野角が得られている26127). 
さらにディスコティック液晶を塗布したフィルムを貼 ることにより黒表示における光漏れを防止して視野角 を拡大する技術 ${ }^{28)}$ が開発されている.

投射型の要素技術として, 高精細化, 高輝度化と構 造の簡略化に関する報告があった. 高温 poly-Si によ る対角 3.3 インチ, 横 $1840 \times$ 縦 1035 画素 3 板式 HDTV 用ライトバルブの試作 ${ }^{29)}$ や, 偏光板が不要な ポリマー分散型液晶を用いた透過型の光学系で 460 $\operatorname{lm}$ の高光束を達成 ${ }^{30)} し$, さらに同様な表示モードで 反射型の光学系とすることで $6.3 \mathrm{~lm} / \mathrm{W}$ の高光利用索

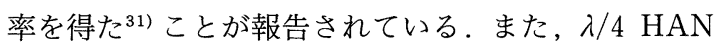
モードと偏光ビームスプリッタを組合せた光学系で従 来の 2 倍の効率が得られている ${ }^{32)}$. 透過型ライトバル ブの開口率向上の課題を集光により解決するマイクロ レンズアレイの微細化が進み, 横 $24 \mu \mathrm{m} \times$ 縦 $34 \mu \mathrm{m}$ のレンズが開発され ${ }^{33)}$, 小型高精細パネルへの適用が 可能となった.

直視型の液晶パネルで 40 インチ以上の大画面化を 実現することを目指す技術として，21 インチ対角の 大型パネル 2 枚を $0.33 \mathrm{~mm}$ の接続間隔で高精度に接 続したマルチパネルの技術 ${ }^{3435)}$ や，レンズとコーン 形状の導光体からなる拡大光学系を挿入してパネル間 のスペースを埋め, 48 枚構成のパネルをタイル状に 並べ 90 インチ対角の大画面表示を実現する技術 ${ }^{36)}$ な どが開発されている.

高速応答化に関連する技術として, フルカラー化 や, 使用温度範囲の拡大など実用化に近づける報告が 見られる. 反強誘電液晶のフルカラー表示をマルチプ レクス法により可能にする技術37) や，選択パルスを 2 分割することにより遷移時間の速いモードを利用し， 低温におけるコントラスト比の低下を防止する駆動法 が開発 ${ }^{38)}$ されるとともに, 強誘電液晶とTFT を組合 せた広視野角，高速応答を目指す技術が開発されてい $ろ^{39)}$.

(鈴木, 津村)

\section{3 CRT}

\subsection{1 直視型 CRT}

1994〜95 年は, パソコンなどのモニタ用 CRT (Color Display Tube：以後 CDT と略す)の生産が年 率 30\%増大し, W/W の生産額で, 家庭用テレビに 用いるCRTの $70 \%$ 程度まで肉薄してきた。 また，表 示内容の高度化により, 対角 $41 \mathrm{~cm}$ (17 型）以上の CDT の普及が本格的に始まった。

このCDTでは，画面の見やすさ，また外光の映り 込みの抑制のためフラット化が進んできており, 運常 でも画面の曲率 $R$ は $1 \mathrm{~m}$ 以上になっているが， $R$ を
無限大とした完全にフラットな CDT が発表されてい $る^{40)}$. 昨年, 国内でも新たな製品化の発表があり，注 目された ${ }^{41)}$.

表示画像の高精細化に伴う偏向周波数の増大は, 電 子ビーム偏向に要する電力消費の増大を招く，一方， 米国の Energy Star や, ドイツの NUTEK のような エネルギー消費を厳しく規制する規格が次第に広まっ てきている．これに対処するため, 偏向ヨークのマウ ントされているネック部の断面積を縮小することによ り, 電力の $20 \sim 30 \%$ 低減を可能とした CDT が発表さ れた。しかし, 細ネック化すると電子銃の電子レンズ 口径が縮小してしまい, その結果, 電子レンズの収差 が増大し, 解像度が低化してしまう。この問題は, 電 子レンズ構造の工夫で解決した ${ }^{42) ~ 44)}$.

LCD では当面量産困難であるといわれている 51 $\mathrm{cm}$ (21 型) 以上の大型分野に対し, CDT がカバーす ることは重要である.大型化に当たっては，例えば A 4 の用紙を 2 枚並べることを考えると, 横長のワイ ドスクリーン化が将来の方向であると思われる. 現 在, 画面横縦比 $16: 9$ の対角 $56 \sim 71 \mathrm{~cm}$ ワイド CDT が発表されている ${ }^{45)}$.

従来, コントラスト向上は表示パネル部の光透過率 を 40〜 50\%程度低下させることで実現していたが， この方法では輝度が低下してしまう. そこで各蛍光体 上に, その発光色に対してのみ透過率の高いフィル夕 を形成した CRT が製品化された ${ }^{46)}$.こうして蛍光体 の発光は透過するが, 反射光の大部分は吸収される. このフィルタと光透過率の高いパネルを組合せれば， 輝度とコントラストの両立を図ることができる. 同一 の反射光強度に対し, 輝度とコントラストがいずれも 20〜 40\%向上した.

\subsection{2 投写型 CRT}

投写型 $\mathrm{CRT}$ は, ここ数年, 米国市場での需要の伸 びが $20 \%$ に達しており, 急速に生産量を増やしてい る.この成長は, 着実に継続されてきた性能改善の努 力の結果であるといえる.

投写型 CRT の性能改善は, 主に電子銃と蛍光体で 進められてきた。電子銃では, 従来から進められてき た 2 重円筒方式大口径レンズ47)が主流になりつつあ るが, さらに将来に期待される技術として, セラミッ クスの抵抗体を用いた電子銃が発表された ${ }^{48)}$. 従来, 電子銃の改良は CRT ネック内径のぎりぎりまで主レ ンズを拡大する方向で進められてきた。しかし本電子 銃は, 寸法は拡大しない。 その代わり主レンズ円筒電 極を高抵抗セラミックスで形成することにより管軸方 向に最適な電位分布を持たせ, 主レンズ収差を大幅に 
低減する。

蛍光体の分野では，まだ実験室段階ではあるが，プ ラズマトーチで蛍光体をいったん溶融させ, 冷却時に 表面張力で球形の結晶とする技術が発表された ${ }^{49}$. 球 形であれば，従来の不定形の蛍光体を用いた場合より も薄い膜厚の蛍光体層を形成できる。したがって, 蛍 光体層内部での光散乱による電子ビームスポット径の 増大による解像度の劣化を抑えることができ, 解像度 が高くなる.また蛍光体の光透過率も高くなるため, 輝度向上にも効果がある. 従来の蛍光体に比較し, 解 像度，輝度とも $10 \%$ 向上すると報告されている．

\subsection{3 要素技術}

寿命特性および解像度向上のため, 電子放出源であ るカソードの研究は継続して行われている. カソード 内に Sc 等の希土類元素を分散させることで電流密度 を高くしても寿命の長いカソードがすでに開発されて いる ${ }^{50)}$.このカソードの結晶状態をコントロールした ところ，エミッション特性が改善された ${ }^{51)}$. 高価では あるが, 高電流密度に対しても寿命の劣化が少ない含 浸型カソードには, 動作電圧が変動してしまうという 問題がある。これに対しては， $\mathrm{Y}_{2} \mathrm{O}_{3}$ の添加により改 善されるという報告があった ${ }^{52)}$.

シミュレーション関係では表面磁荷法を用いた偏向 磁界特性の総合的解析プログラムの発表があった ${ }^{53)}$. 偏向ヨークのコンバーゼンス特性, 偏向感度, 渦電 流, VLMF (Very Low Magnetic Field), フェライ トシート添付によるミスコンバーゼンス補正等を解析 することができる．

外光の映り込みによる視認性低下，および帯電を防 ぐため, 表示パネル部表面へのコーティングが一般的 になってきた。この多層 AR(Anti Reflection)コート を施す前に，フィルムをパネル表面に貼る技術が発表 された、コーティングの生産性が向上し，また，パネ ルの研磨工程を省略できる効果もある。電磁波漏洩と 視認性に対しては, 低抵抗の ITO 層を形成すること, フィルムや接着剤の屈折率を調整することで，規格 (TCO, TUV) を満たすことができる ${ }^{54)}$.

(白井)

\subsection{PDP}

PDP は, 家電メーカーから 40 インチクラスの大型 カラーDPD の開発, 製品化, さらに設備投資に向け ての意欲的な計画が相次いで発表されるなど，ここ 1〜2 年の間に大きな動きが見られた.

$\mathrm{AC}$ 型では, 対角 42 インチ, 横 $852 \times$ 縦 480 画素 (RGB で 1 画素) の PDP が開発された ${ }^{55)}$. 輝度は 300 $\mathrm{cd} / \mathrm{m}^{2}$ で, 動画像に対する画質改善(後述)のため,
誤差拡散とフレーム間変調を併用することにより 256 階調を得ている. また, 対角 40 インチ, 横 $840 \times$ 縦 480 画素, 輝度 $200 \mathrm{~cd} / \mathrm{m}^{2}, 256$ 階調の PDP も試作さ れた ${ }^{56)}$.さらに, 40 インチクラスの PDP が何種類か 試作され，エレクトロニクスショーなどで展示され た、いずれの PDP の構造も面放電型で, 前面にペア の維持電極, 背面にアドレス電極とストライプ状の隔 壁と蛍光体を持つ構造である。これ以外の構造では, 障壁上に電極を形成したものや57)，メモリーシートと 呼ばれる誘電体で覆われた金属シートを利用した $\mathrm{AC} / \mathrm{DC}$ ハイブリッド型 $\mathrm{PDP}^{58)}$ が報告されている. また, 電極保護層の $\mathrm{MgO}$ 膜を, 従来の電子ビーム蒸 着ではなく，厚膜印刷で形成する方法も検討されてい $3^{59) 60)}$.

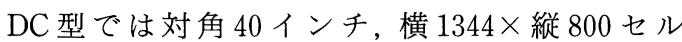
(RGB それぞれを 1 セルと数える), 輝度 $150 \mathrm{~cd} / \mathrm{m}^{2}$, 256 階調の PDP が試作された ${ }^{61)}$ 。また, 対角 26 イン チ, 横 $896 \times$ 縦 512 セルのPDP も開発された ${ }^{62)}$.こ れらのパネルは, 封入ガス圧を高めるとともに各放電 セルに電流制限用抵抗を設け，長寿命を得ている。 ま た従来, 表示セルのみに電流制限用の抵抗を付けてい たものを, 補助セルにも付けて動作の安定化を図っ $た^{63)}$. 放電セル微細化のためには，母線上に抵抗を形 成して抵抗を高密度実装する構造も検討されてい $る^{64)}$. 発光効率改善の点では, 陰極に ITO (Indium Tin Oxide）を用い開口率を改善した PDP が報告され た ${ }^{65)}$ 。さらに，DC 型の駆動法であるパルスメモリー 駆動法の省電力化や66), 駆動用 IC の開発が行われ $た^{67)}$.

一方, 大型 PDP を精度良く形成するために, 従来 障壁等の形成に用いられてきた厚膜印刷の改善ととも に, 感光性厚膜材料を用い, 光プロセスによりパター ンを形成する技術も検討されている ${ }^{68)}$.

画面サイズの拡大に伴い, PDP の画質の問題がク ローズアップされてきた。特に動画像表示時に現れる 擬似輪郭状ノイズが問題となってきている。これは, PDP の中間調の表示法が，ビットに相当する重み付 けをした 2 階調の画面を時間的に重ねて行う方式であ り，視線が動くとこの重㸚合わせが正しく行われない ことから発生する。これに対して，ビットの順番を入 れ替える，上位のビットを分割する，さらに，2 進法 によらない重み付けを行う等の対策が発表され た ${ }^{55(69) 70)}$ 。また, 蛍光体の輝度飽和によって起こる階 調の不連続性とその対策も報告された ${ }^{71)}$.

(高野) 


\subsection{EL， LED， DMD}

薄膜 ELD（Electroluminescent Display）は固体発 光素子であり, また, 素子厚が $1 \sim 2 \mu \mathrm{m}$ 程度と薄 い。これらの特徴を活かして画素サイズが $10 \mu \mathrm{m}$ 程 度の超高精細ディスプレイが作製可能であり, HMD (Head-Mounted Display) への応用が期待されてい る. 最近, SOI（Silicon on Insulator）技術を用いて, EL 素子駆動用の高耐圧 DMOS-FET とデータ用の CMOS-FET を集積し，その上に EL 素子を積層した AM (Active Matrix) EL を用いて MHD 用の ELD が 開発された ${ }^{72)-74)}$. 画素数は横 $1280 \times$ 縦 1024 , 表示面 積は $1.2 \times 1$ in $(30 \times 25 \mathrm{~mm})$ であり，画素ピッチは 25 $\mu \mathrm{m}$ (1000 lpi) である. AMEL を用いることによりメ モリー駆動が可能となり, PDP と同様な輝度データ の書込みと発光回数の制御方式で, 64 階調 (6ビット) の中間調を得ている. EL 素子の駆動周波数は 3 $\mathrm{kHz}$, 輝度 $140 \mathrm{~cd} / \mathrm{m}^{2}$ である. 重量 $6 \mathrm{~g}$, 消費電力 2 $\mathrm{W}$ ，周辺部を含めたサイズは $1.3 \times 1.1$ in $(33 \times 28$ $\mathrm{mm}$ ) とコンパクトであり, HMD として広く用いら れることが期待される。

ELD のマルチカラー化, フルカラー化の研究・開発 も活発に行われている ${ }^{75)}$. 青色 $\mathrm{EL}$ 材料 $\mathrm{CaGa}_{2} \mathrm{~S}_{4}: \mathrm{Ce}$ の特性改善が進み, 対角 5 in, 画素数横 $320 \times$ 縦 256 の R, G, B マルチカラー (16 色) ELD が市販された. 緑色には $\mathrm{ZnS}: \mathrm{Tb}$, 赤色には $\mathrm{ZnS}: \mathrm{Mn}$ 発光を $\mathrm{CdS}_{x} \mathrm{Se}_{1-x}$ でフィルタしたものが用いられている. 輝 度は $30 \mathrm{~cd} / \mathrm{m}^{2}$ であり, 高いコントラスト比(500 lx の 照明下で $20: 1)$ と，広視野角という特徵を有してお り, 医療機器などのディスプレイへの応用が期待され る ${ }^{76)}$. また, 青色 EL として従来の SrS : Ce を使用し て同様な構造の車載用マルチカラーELD が開発され $た^{77)}$.

ブロードな発光スペクトルをもつ $\mathrm{ZnS}: \mathrm{Mn} / \mathrm{SrS}$ : Ce EL 発光層とカラーフィルタを組合せた構造の ELD の特性改善も進んでいる. 対角 $10 \mathrm{in}$, 画素数横 $320 \times$ 縦 256 , 輝度 $21 \mathrm{~cd} / \mathrm{m}^{2}$, コントラスト比 $(1000$ 1x で $30: 1,10,0001 \mathrm{~lx}$ で 4:1)の R, G, B マルチカ ラーELD が報告された ${ }^{78)}$.

有機 ELについては, Tang らによるブレークスル 一となる技術の提案から 10 年近くが経過した ${ }^{79}$. 当 初, 寿命が短いことが最も解決困難な課題とされてい たが, 最近, 輝度半減寿命で 5000 時間以上が達成さ れつつある. 簡単な文字・数字表示パネルではあるが， ALQ と TPD を用いた色素蒸着タイプ有機 ELD の市 販が報告された ${ }^{80)}$. 有機 EL のカラー化技術として,
青色発光有機 EL と CCM (Color Changing Media) を組合せた， R, G，B マルチカラーELD の試作例 が報告された ${ }^{81}$. 今後画素数の多い, 高い情報表示密 度をもつ有機 ELD の開発が課題である.

LED に関しては, InGaN / AlGaN ダブルヘテロ構 造を持つ青色発光 LED の特性向上がめざましい ${ }^{82}$. $3.6 \mathrm{~V}, 20 \mathrm{~mA}$ で駆動したとき, 出力 $3 \mathrm{~mW}$, 軸方向 光度 $2.5 \mathrm{~cd}$ が得られている. 外部量子効率は $5.4 \%$, ピーク波長は $450 \mathrm{~nm}$ である。緑色 LEDには従来 $\mathrm{GaP}: \mathrm{N}$ が用いられてきたが, 光度は $0.1 \mathrm{~cd}$ 程度と 低く, 発光色も黄色味を帯びていた。これに対して, $\mathrm{InGaN} / \mathrm{AlGaN}$ 単一量子井戸構造を用いて, $20 \mathrm{~mA}$ 駆動で出力 $3 \mathrm{~mW}, 12 \mathrm{~cd}$, 外部量子効率 $6.3 \%$ の純緑 色 $(520 \mathrm{~nm})$ LED が開発された ${ }^{83)}$. 赤色 LED では GaAlAs ダブルへテロ構造を用いて 3〜 $5 \mathrm{~cd}$ が得られ ており,これで高輝度フルカラーの屋外用大型ディス プレイの実現が可能となった。

DMD の研究はすでに 20 年を越えるが, 最近完成 度の高いデバイスの発表が続いている ${ }^{84)}$. 画素数横 $1280 \times$ 縦 1024 , ピッチ $17 \times 17 \mu \mathrm{m}$, 基板は $1 / 2$ イン チシリコン. C-MOSメモリーの $0.8 \mu \mathrm{m}$ 標準プロセ スを用いるため, 信頼性は高い. 出力 $200 \mathrm{~lm}$ で, DMD 本体の温度はほぼ室温であった。寿命は 1 〜 年で，鏡の動きを支えている部分の故障は皆無であっ た. 欠陷数 $0 \sim 2$ 個のものが $95 \%$ を占める.

（田中）

\section{6 FED}

FED (Field Emission Display) は, すべての画素 に対して電子銃が $1: 1$ に対応して形成された自発光 型ディスプレィで, CRT と同等の画質でありながら, 厚さも消費電力も LCD 以下という特徴をもってい $3^{85) 86)}$.

FED 最大の技術課題は，いかにして長寿命・大電流 の電子銃を実現するかという点にあり，これは研究が 活発化した 1980 年代後半から変わっていない。これ まで様々な形状, 材料のフィールドエミッタアレイ (FEA) が提案試作されてきたが87)88)，これらはスピ ント型, シリコンコーン型, およびその他の 3 種類に 分類できる.

スピント型は，現在発表されている FED のほとん どで利用されている.スピント型FED の開発経緯を 示す興味あるデータが，昨年米国で開催された国際会 議(IVMC 96)で双葉電子工業から発表された ${ }^{89}$. そ れによると, 1993 年にはわずか 10 時間程度であった 寿命が, 1995 年には 5000 時間以上に延びている.こ の背景には, 真空封止や蛍光体塗布技術などに対し 
て, VFD(Vacuum Fluorescent Display)開発で培っ てきた膨大なノウハウが役に立ったと思われるが, 特 に，エミッタとその下部に挿入する抵抗層との接続方 法を独自に考案した点が大きい. LETI が開発し PixTech 社に引き継がれているメッシュ構造90)に代わつ て, アイランド構造が提案されている ${ }^{91)}$.これは, 抵 抗層内の FEA 形成領域だけに金属電極を付加し, そ れに連なる FEA 全体を同電位に保持できるようにし ている. 従来 FEA の中心部と周辺部で付加抵抗が異 なることから, 中心部で電流が減少してしまうという 欠点があったが, これが克服でき, 結果として電流を 2 倍以上流せるようになった。

$\mathrm{Si}$ のコーン型エミッタでは, 上で述べた抵抗層の 代わりに, p-n 接合や FET (電界効果トランジス夕) をエミッタに直列に接続し, 電流の安定化や均一化を 図っている. 市販の FET を用いた簡単な実験で, 電 流が安定したという報告がされている ${ }^{92)}$. 最近, 橋口 らはFETやFEAのモノリシックー体形成に成功し ている ${ }^{93)}$. ただし, FEAに加えて FET 構造を別途 作製するのは技術的にもコスト的にもかなり厳しい. そこで, ティップごとに簡単な $\mathrm{n}-\mathrm{p}$ 接合をイオン注 入法で作製する方法が提案されている ${ }^{94)}$.これは, 接 合の逆方向電流でエミッション電流を限定し, 結果と して安定化させようとするものである. 今後, できる だけ簡単な構造で電流制御機能を付加した FEA の開 発が鍵となるが, これが実現すれば, 従来からの宿命 的な不安定性や破壞の問題が大幅に改善されよう.

(伊藤)

\section{$2.73 \mathrm{D}$ ディスプレイ}

$3 \mathrm{D}$ ディスプレイは, 立体テレビ放送の実現を目指 した研究開発にとどまらず, 画像通信, コンピュータ グラフィックス, バーチャルリアリティといった将来 性のある分野におけるキーテクノロジーと位置付けら れ, 従来に増して活発な研究開発が進められた。

両眼視差に基づく $3 \mathrm{D}$ ディスプレイに関しては, 実 用化を意識した各種メガネなし方式の開発が盛んであ った、まずレンチキュラ方式では, 立体プロジェクシ ヨンテレビの開発 ${ }^{95)}$, 八イビジョン用多眼方式 $3 \mathrm{D}$ デ イスプレイの高性能化 ${ }^{96)}$, 複数人を独立に追従する方 式の提案 ${ }^{97)}$ などがあげられる。また、レンチキュラ 方式と類似のパララックスバリア方式では, 高精度な バリアを用いた高品質な立体液晶ディスプレイが開発 された ${ }^{98)}$.さらに大凸レンズ方式を用いた, 観察者に 自動的に追従して立体視域が変化するバックライト分 割と呼ばれる新しいディスプレイが提案された ${ }^{99)}$.
一方, 将来の $3 \mathrm{D}$ ディスプレイと期待されるホログ ラフィに関しては, 空間光変調器に液晶を使う構成で 入力に CCD カメラを用いるもの ${ }^{100)}$, 表示サイズや解 像度の改良を行ったもの ${ }^{101)}$, および, 空間光変調器 に音響光学素子を用いる構成で静的な光学ホログラム と動的な電子ホログラムを合成する方法 ${ }^{102)}$ などが報 告された。また, 多眼式に属する方式であるが, 複数 の微小回折格子を 1 画素内に配置するグレーティング イメージ103)や, partial-pixel ${ }^{104)}$ と呼ばれる新しい デバイスが提案された．さらに，ホログラフィの光走 查技術を用いた多眼式として, 微小 LED アレイの発 光をポリゴンミラーでスキャンする方式が提案され $た^{105)}$.

体積ディスプレイに関しては, ディスプレイ自身が 運動するタイプとして CRT 内の蛍光面が回転するデ バイス ${ }^{106)}$,ディスプレイ自身は運動せずにファイバ 束の端面が発光するデバイス ${ }^{107)}, 2$ 段階光励起を用 いる方法 ${ }^{108)}$ などが提案された。

また，3Dディスプレイの実用化が近づいたことか ら, 見やすさや疲労感に対する研究も盛んになり, 両 眼視差に基づくものでありながら幅輳と焦点調節が連

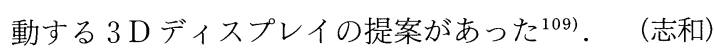

\section{8 む す び}

巷には「マルチメディア」や「インターネット」と いう言葉が溢れている. 大画面のテレビ, コンピュー 夕端末兼用ディスプレイに対する要求がますます強く なろう。液晶事業は決して順風満帆とはいえないにも かかわらず, 2001 年には 1.5 兆円の市場が予想され ている。液晶ビジネスは日本が世界の主導権を得た が, プラズマに対しても同様なことが起こりつつあ る。これが新たな貿易摩擦を引き起こさないか，と考 えるのは杞憂であろうか. PDP はディスプレイ業界 に旋風を巻き起こしているが, しかし, 画像表示特性 はまだ CRT に劣る。現在各社ともほほ同様なパネル 寸法や放電セル構造を採用している。これらを仮りに 第 1 世代と呼べば，各社それぞれが持ち味を出した， かつCRT と同程度の特性を有する PDP が第 2 世代 であろう。しかしこの到来は, 次回の年報には間に合 うまい. ELやFEDは，LCD といかに棲み分けるか が課題である。

(御子柴)

(1996 年 3 月 15 日受付)

\section{【参 考 文 献〕}

1) H. Hayashi, et al.: "Fabrication of Low Temperature BottomGate Poly-Si TFTs on Large-Area Substrate by Linear-Beam Excimer Laser Crystallization and Ion Doping Method", Proc. 
1995 IEDM, pp. 829-832 (1995)

2) S. Inoue, et al.: " $425^{\circ} \mathrm{C}$ Poly-Si TFT Technology and Its Applications to Large Size LCDs and Integrated Digital Data Drivers", Proc. Asia Display 95, pp. 339-342 (1995)

3) T. Morita, et al. : "VGA Driving with Low Temperature Processed Poly-Si TFTs”, Proc. 1995 IEDM, pp. 841-843 (1995)

4) F. Okumura, et al. : "A 76-mm (3-in.) Driver-Integrated Poly-Si TFT-LCD Light Valve”, SID 94 Digest, pp. 79-82 (1994)

5) K. Sano, et al.: "Excimer Laser Activation in Ion Doped Poly-Si Films and Its Application to High-Mobility Poly-Si TFTs", AM -LCD 94 Digest, pp. 104-107 (1994)

6) R. G. Stewart, et al. : "Circuit Design for a-Si AMLCDs with Integrated Drivers”, SID 95 Digest, pp. 89-92 (1995)

7) H. Kanoh, et al.: "A 23-cm-Diagonal Bright Reflective GuestHost TFT-LCD”, SID 95 Digest, pp. 333-336 (1995)

8) T. Miyashita, et al.: "Properties of the OCB Mode for ActiveMatrix LCDs with Wide Viewing Angle", SID 95 Digest, pp. 797 -800 (1995)

9) T. Uchida, et al. : "A Novel Reflective LCD for High Resolution Color Display”, Proc. Asia Display 95, pp. 599-602 (1995)

10) L.-C. Chien, et al. : "Multicolor Reflective Cholesteric Display", SID 95 Digest, pp. 169-172 (1995)

11) M. Pfeiffer, et al.: "A High-Information-Content Reflective Cholesteric Display”, SID 95 Digest, pp. 706-709 (1995)

12) J.L. West, et al.: "Flexible Displays Utilizing Bistable, Reflective Cholesteric/Polymer Dispersions and Polyester Sub strates", Proc. Asia Display 95, pp. 55-57 (1995)

13) S.S. Kim, et al.: "High Aperture and Fault-Tolerant Pixel Structure for TFT-LCDs”, SID 95 Digest, pp. 15-18 (1995)

14) T. Gunjima, et al.: "New Back-Lighting Device for Liquid Crystal Displays”, Proc. Asia Display 95, pp. 731-734 (1995)

15) D. J. Broer, et al.: "Reflective Cholesteric Polariser Improving the Light Yield of Back-and Side-Lighted Flat Panel Liquid Crystal Displays", Proc. Asia Display 95, pp. 735-738 (1995)

16) A. Horibe, et al.: "Brighter Backlights using Highly Scattered Optical-Transmission Polymer”, SID 95 Digest, pp. 379-381 (1995)

17) M. Akiyama, et al. : A 13.8-in.-Diagonal 1-Mpixel TFT-LCD with Light-Shield Fully Self-Aligned TFTs”, SID 95 Digest, pp. 158-161 (1995)

18) N. Ichikawa, et al.: "Holographic Optical Element for Liquid Crystal Projector”, Proc. Asia Display 95, pp. 727-730 (1995)

19) G. Itoh, et al. : "Advanced Multi-Field-Driving Method for Low Power TFT-LCD”, Proc. Asia Display 95, pp. 493-496 (1995)

20) H. Nitta, et al.: "A Driver LSI with Internal RAM for Low Power STN-LCD”, Proc. Asia Display 95, pp. 877-880 (1995)

21) T. Suzuki, et al. : "33-cm-Diagonal Full-Color Wide-ViewingAngle C-TN LCD for Use in a Workstation”, SID 94 Digest, pp. 267-270 (1994)

22) H. Yoshida, et al.: "Wide Viewing Angle Full-Collor TFTLCDs", AM-LCD 94 Digest, pp. 52-55 (1994)

23) S. Kobayashi, et al.: "Amorphous and Super-Multi Domain AM -LCDs Exhibiting Uniform and Wide Viewing Angle Characteristics and Exellent Grayscale Capability", AM-LCD 94 Digest, pp. 40-43 (1994)

24) T. Hashimoto, et al. : "TN-LCD with Quarered Subpixels Using Polarized UV-Light-Irradiated Polymer Orientation Films", SID 95 Digest, pp. 877-900 (1995)

25) J. Chen, et al.: "Four-Domain TN-LCD Fabricated by Reverse Rubbing or Double Evaporation", SID 95 Digest, pp. 865-868 (1995)

26) M. Oh-e, et al. : "Principles and Characteristics of Electro-Optical Behaviour with In-Plane Switching Mode", Proc. Asia Display 95 , pp. 577-580 (1995)

27) M. Ohta, et al.: "Development of Super-TFT-LCDs with In Plane Switching Display Mode”, Proc. Asia Display 95, pp. 707710 (1995)

28) J. Mukai, et al. : “A Viewing-Angle Compensator Film for TFT -LCDs”, Proc. Asia Display 95, pp. 949-950 (1995)

29) M. Kobayashi, et al. : "High-Mobility Poly-Si TFTs with Tungsten-Polycide Gate for 1.9-Mpixel HDTV LCD Projector”, SID 94 Digest, pp. 75-78 (1994)
30) S. Shikama, et al. : "High-Luminance LCD Projector Using a-Si TFT-PDLC Light Valves", SID 95 Digest, pp. 231-234 (1995)

31) Y. Ooi, et al. : "Refrective-Type LCPC Projection Display", SID 95 Digest, pp. 227-230 (1995)

32) J. Glueck, et al. : "Refrective TFT-Addressed LC Light-Valve TV Projectors with High Light Efficiency", SID 95 Digest, pp. 235 -238 (1995)

33) H. Hamada, et al.: "A New High Definition Microlens Array Built in p-Si TFT-LCD Panel”, Proc. Asia Display 95, pp. 887890 (1995)

34）日経マイクロデバイス, pp. 121-130 (1995)

35) M. Hijikigawa, et al. : "Future Prospects of Large-Area DirectView LCDs", SID 95 Digest, pp. 147-150 (1995)

36) M. Fukuhara, et al.: "LCD Multi-Panel Display", Proc. Asia Display 95, pp. 197-200 (1995)

37) Y. Yamada, et al.: "A Full-Color Video-Rate Anti-Ferroelectric LCD with Wide Viewing Angle”, SID 95 Digest, pp. 789 -792 (1995)

38) N. Koshoubu, et al.: "Driving Technique in Full-Color AntiFerroelectric Liquid Crystal Display”, Proc. Asia Display 95, pp. 69-72 (1995)

39) K. Nito, et al. : "TFT-Driven Monostable Ferroelectric Liquid Crystal Display with Wide Viewing Angle and Fast Response Times", AM-LCD 94 Digest, pp. 48-51 (1994)

40) C. J. Prazak III, et al. : "Electronic Imaging '86 (1986)

41) K. Werner: "Japan Marathon”, Information Display, 12, p. 35 (1966)

42) S. Shirai, et al. : "Small-Neck Color Display Tubes with Narrow -Elliptical-Aperture-Technology (NEAT) Electron Gun", Proc. IDRC, pp. 468-471 (1994)

43）星野ほか：“ミニネック CDT 用電子銃の開発”，テレビ学技報， 19, IDY95-10, pp. 1-6 (1995)

44）相原ほか：“36 cm (15 型) 省電力カラーディスプレイ管”, NEC 技 報, 48, pp. 208-209 (1995)

45) H. Nose, et al. : "Development of $56 \mathrm{~cm}$ Wide Color Display Tube”, Proc. Asia Display 95, pp. 749-752 (1995)

46) T. Inoue, et al. : “Microfilter'TM Color CRT”, SID 95 Digest, pp. 25-27 (1995)

47）木村ほか：“超高解像度ディスプレイ管”, テレビ学技報, ED626, pp. 21-26 (1982)

48) T. Muchi, et al. : "Study of Electrostatic Lens for CRTs Composed of High Resistivity Ceramics", Proc. IDRC, pp. 229-232 (1994)

49) A. K. Aibessard, et al.: "Phosphor Layers Made of Spherical Particles", Proc. Asia Display 95, pp. 643-646 (1995)

50) H. Nakanishi, et al. : "Oxide-Coated Cathode for CRT Use at High Current Density”, Proc. SID, 31, pp. 165-169 (1990)

51) T. Ozawa, et al. : "A Novel Crystal State of $\mathrm{Ba} / \mathrm{Sr}$ Carbonates Improving the Cathode Emission Properties", Proc. Asia Display 95 , pp. 763-766 (1995)

52) H. Nakanishi, et al. : "A New Type Dispenser Cathode Coating $\mathrm{Y}_{2} \mathrm{O}_{3}$ for CRTs”, Proc. IDRC, pp. 176-179 (1994)

53) T. Nakagawa, et al.: "Computer Program for Design Study of CRT”, Proc. Asia Display 95, pp. 753-756 (1995)

54) T. Saito, et al.: "Application of Engineering Film and Adhesive for Trinitron Tube", SID 95 Digest, pp. 28-31 (1995)

55) T. Makino, et al.: "Improvement of Video Image Quantity in AC -Plasma Display Panels by Suppressing the Unfavorable Coloration Effect with Sufficient Gray Shades Capability", Proc. Asia Display 95, pp. 381-384 (1995)

56) T. Nakamura, et al.: "Drive for 40-in.-Diagonal Full Color ac Plasma Display”, SID 95 Digest, pp. 807-810 (1995)

57) Y. Kawai, et al.: "High Luminance and High Luminous Efficiency in Barrier-Electrode Color ac Plasma Displays Fabricated by Sand Blasting Technology", SID 95 Digest, pp. 815818 (1995)

58）天野: “AC/DCハイブリッド型 PDP”，テレビ学技報， 18，43, IDY94-109, pp. 7-12 (1994)

59）小岩ほか：“AC-PDP 用印刷 $\mathrm{MgO}$ 保護膜の均一性向上の検討”, テ レビ学技報, 19, 2, IDY95-16, pp. 31-36 (1995)

60）伊藤ほか：“AC-PDP 用印刷透明保護膜”，テレビ学技報， $\mathbf{1 9} ， 2$, IDY95-17, pp. 37-41 (1995) 
61) J. Koike, et al.: "Long-Life, High Luminance 40-in. Color DC PDP for HDTV", Proc. Asia Display 95, pp. 943-944 (1995)

62) H. Kono, et al.: "A Long-Life dc Color PDP with a Concave Cathode", SID 95 Digest, pp. 823-827 (1995)

63) K. Sasaki, et al.: "Discharge Characteristics of Full-Color Plasma Display Panels with Resistors in Display and Auxiliary Cells", SID 95 Digest, pp. 819-822 (1995)

64) K. Ishii, et al.: "New Resistor Structure of Long-Life DC Plasma Display Panels", Proc. Asia Display 95, pp. 393-396 (1995)

65) Y. Motoyama and J. Koike: "Long-Life Color DC-PDP with Transparent Cathode", Proc. IDRC, pp. 460-463 (1994)

66) Y. Takano, et al.: "A 40-in. DC-PDP with New Pulse-Memory Drive Scheme", SID 94 Digest, pp. 731-734 (1994)

67) T. Tamura, et al.: "Development of Color dc Plasma Display Driver ICs for Pulse-Memory Driving Method", SID 94 Digest, pp. 723-726 (1994)

68) J. J. Felton, et al. : "Thick-Film Materials for Plasma Displays", SID 95 Digest, pp. 488-490 (1995)

69) T. Masuda, et al.: "New Category Contour Noise Observed in Pulse-Width-Modulated Moving Imges", Proc. IDRC, pp. 357360 (1994)

70) K. Toda, et al.: "A Modified-Binary-Coded Light-Emission Scheme for Suppressing Gray Scale Disturbances of Moving Images", Proc. Asia Display 95, pp. 947-948 (1995)

71）牧野ほか：“蛍光体の輝度飽和とカラーPDP の輝度特性”, テレビ 学技報, 19, 2, IDY95-19, pp. 49-54 (1995)

72) R. Khormaei, et al.: "High-Density Active Matrix Electroluminescent Display", SID 94 Digest, pp. 137-139 (1994)

73) R. Khormaei, et al. : "A $1280 \times 1024$ Active-Matrix EL Display", SID 95 Digest, pp. 891-893 (1995)

74) F. L. Hsueh, et al.: "Design of a High-Density, Gray Scale, 1280 $\times 1024$ Active-Matrix EL (AMEL) Display on SOI", Proc. Asia Display 95, pp. 283-286 (1995)

75) R. T. Tuenge: "Recent Progress in Color Thin Film EL Display Panels", Proc. Asia Display 95, pp. 279-282 (1995)

76) W. Barrow, et al.: "A High Contrast, Full Color 320.256 Line TFEL Display", Proc. 14th IDRC, pp. 449-451 (1994)

77) A. Kato, et al. : "An RGB 8-Color EL Display in a Stacked Panel Configuration Using Unfiltered SrS : Ce”, Proc. Asia Display 95, pp. 287-290 (1995)

78) J. Haaranen, et al.: “ $512(\times 3) \times 256$ RGB Multi-Color TFEL Display Based on Color by White”, SID 95 Digest, pp. 883-886 (1995)

79) C. W. Tang and S. A. VanSlyke: "Organic Electro-luminescent Diodes”, Appl. Phys. Lett., pp. 913-915 (1987)

80) J. Funaki, et al.: "Electroluminescence of the Devices Using Pyrazoloquinoline Derivatives", Proc. Asia Display 95, pp. 265268 (1995)

81) M. Matsuura, et al. : "Performance of RGB Multi-Color Organic EL Display", Proc. Asia Display 95, pp. 269-272 (1995)

82) S. Nakamura: "High-Brightness Blue LEDs Using III-V Nitrides and Their Applications", SID 95 Digest, pp. 713-716 (1995)

83) S. Nakamura, et al.: "High-Brightness InGaN Blue, Green and Yellow Light-Emitting Diodes with Quantum Well Structures", Jpn. J. Appl. Phys., 34, pp. L797-799 (1995)

84) R. Howell and M.A. Mignardi: "Fabrication of the Digital Micromirror Device (DMD)", 1996 Display Manuf. Tech. Conf.,
Digest Tech. Papers, pp. 79-80 (1996)

85）日経バイト, “FED の登場は 1997 年”, p. 189 (1995)

86）日経エレクトロニクス, “FED と有機 EL が液晶パネルに挑戦“, pp. 85-103 (1996)

87) H. H. Busta: "Vacuum Microelectronics-1992", J. Micromech. Microeng., 2, pp. 43-74 (1992)

88）伊藤順司：“真空マイクロエレクトロニクス”, 信学誌, 77 , pp. 11821186 (1994)

89) T. Kishino and S. Itoh: "Present Status of the FED Development and Problems to Solve", Tech. Dig. 8th Int. Vacuum Mi croelectronics Conf., Portland, USA, 30/Jul-3/Aug, 1995, pp. 1-6 (late paper)

90) J. Levine "Benefits of the Lateral Resistor in a FED, ibid., pp. 67 -71 (1995)

91) S. Itoh, et al. : "A New Structure of Field Emitter Arrays", ibid., pp. 99-102 (1995)

92) K. Yokoo, et al.: "Active Control of the Emission Current of Field Emitter Arrays”, J. Vac. Sci. Technol., B13, pp. 491-493 (1995)

93）橋口 原, 三村秀典, 藤田博之: “モールド法による TFT 積層型ポ リシリコン電子銃アレイの試作”, 学術振興会第 158 委員会第 11 回 研究会資料, pp. 8-12 (1995)

94) T. Hirano, et al.: "Emission Characteristics of Ion-implanted Silicon Mitter Tips", Jpn. J. Appl. Phys., 34, pp. 6907-6911 (1995)

95）金山ほか：“メガネなし $3 \mathrm{D}$ 液晶ディスプレイ”, SANYO TECH NICAL REVIEW, 26, 2, pp. 8-15 (1994)

96）磯野ほか：“8眼式メガネなし 3 次元テレビジョン”，テレビ誌， 48 10, pp. 1267-1275 (1994)

97）大村ほか：“複数人観測可能な視点追従型レンティキュラー立体表 示装置”, 3 次元画像コンファレンス '94 論文集, pp. 233-238 (1994)

98) G. Hamagishi, et al.: "New Stereoscopic LC Displays without Special Glasses”, Proc. Asia Disply 95, pp. 791-794 (1995)

99）大森ほか：“バックライト分割方式ステレオディスプレイシステ ム”, 3 次元画像コンファレンス '94 論文集, pp. 219-224 (1994)

100）橋本：“液晶 TV を用いた電子ホログラムディスプレー”,テレビ学 技報, 19, 16, AIT' '95-2, pp. 5-8, (1995)

101）深谷ほか：“LCD を用いたホログラフィックディスプレイにおける 表示像拡大法”, 3 次元画像コンファレンス '94 論文集, pp. 165-170 (1994)

102）泰間ほか：“光学ホログラムとの合成により画質改善したリアル夕 イム電子ホログラフィ”, テレビ誌, 48, 10, pp. 1245-1252（1994）

103）高橋ほか: “グレーティングイメージを用いた立体像表示システ ム”, 3 次元画像コンファレンス '95 論文集, pp. 64-69 (1995)

104) G. P. Nordin, et al.: "Demonstration of a Novel Three-dimensional Autostereoscopic Display", Optics Letters, 19, 12, pp. 901903 (1994)

105）梶木：“集束化光源列による多眼式立体ディスプレイの提案”，3D 映像, 9, 3, pp. 3-8 (1995)

106) B. G. Blundell, et al.: "Cathod Ray Sphere: a prototype system to display volumetric three-dimensional images", Optical Engineering, 33, 1, pp. 180-186 (1994)

107) D. L. MacFarlane: "Volumetric Three-dimensional Display", Applied Optics, 33, 31, pp. 7453-7457 (1994)

108) E. A. Downing, et al.: "A Solid-State Three-Dimensional Upconversion Display", 1994 IEEE Nonlinear Opt. Mater. Fundam. Appl., pp. 409-411 (1994)

109) S. Shiwa, et al.: "A New Binocular Parallax Display Method in Which Vergence Changes are Linked to Accommodative Responses", Proc. Asia Display 95, pp. 785-788 (1995) 